\title{
The Effects of Stereochemistry of the Bridging Atoms in $o$-Substituted Arylbenzoic Acids on Root Antigravitropism
}

\author{
Tsutomu TeITEI \\ Division of Plant Industry, CSIRO, P.O. Box 1600, Canberra City A.C.T. 2601, Australia
}

Received September 20, 1982

\begin{abstract}
Compounds in which an aryl or heteroaryl ring is linked to the ortho position of a benzoic acid moiety by a bridging group of up to four atoms are shown to inhibit the gravitropic response of cress seedling roots between $10^{-5}$ and $10^{-8} \mathrm{M}$. No significant difference in inhibitory activity is observed between compounds containing up to four saturated or two partially unsaturated bridging atoms, although analogues containing three or four partially unsaturated bridging atoms are one to two orders of magnitude more active. Compounds in which the aryl nuclei are fused together are shown to be inactive at the highest concentration tested. The results have been interpreted in terms of the aryl groups in the molecule interacting with a hypothetical receptor site, with the bridging atoms acting as a more or less flexible coupling to facilitate such interaction.
\end{abstract}

The plant growth-regulating properties of 2-(1,3-dione-3-phenylpropyl)benzoic acid (27) were first observed in these laboratories in 1972. ${ }^{1)}$ This compound was found to interfere with the normal gravitropic response of seedling roots, to overcome apical dominance, and to inhibit the polar transport of auxin through plant tissue.

Studies of the effects on root gravitropism of various series of compounds related to (27) and other $o$-substituted benzoic acids ${ }^{2)}$ have indicated that activity was associated with compounds containing an $o$-carboxyphenyl ring $\left(\mathrm{Ar}_{1}\right)$ attached to a second aryl group $\left(\mathrm{Ar}_{2}\right)$ by a partially unsaturated bridging system (group X) (Fig. 1).

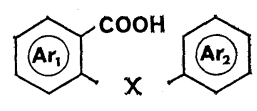

FIG. 1.

At first, it was considered that some degree of conjugation between the two aryl regions of the molecule, which would have allowed a coplanar configuration of the aryl groups and the bridging atoms to be achieved, was necessary for activity. ${ }^{2 b, c)}$ Later, however, results obtained from a study of $o$-alylethenylbenzoic acids $^{3}$ cast doubt on the importance of this co-planarity for activity. It has been shown that there is no significant difference in the activity between the supposedly co-planar (among $\mathrm{Ar}_{1}, \mathrm{X}$ and $\mathrm{Ar}_{2}$ ) trans-isomers and the non-planar (between $\mathrm{Ar}_{1}$ and $\mathrm{Ar}_{2}$ ) cis-isomers, implying that co-planarity may not be a necessary requirement for high activity. Recently, Katekar and Geissler ${ }^{4}$ have suggested that such a co-planar configuration was not a prerequisite for anti-gravitropic activity, but was rather unfavourable for it. They suggested that for compounds to be active the portion of the molecule attached to the arylcarboxylic acid $\left(\mathrm{Ar}_{1}\right)$ should be planar or capable of being so, i.e. that the bridging atoms $(\mathrm{X})$ and the aryl group $\left(\mathrm{Ar}_{2}\right)$ should be co-planar or capable of being so. The present work was undertaken to examine the effect of the stereochemistry of the bridging atoms $(\mathrm{X})$ in $o$-substituted benzoic acids (Fig. 1) on root antigravitropic activity.

\section{EXPERIMENTAL}

Melting points are uncorrected and were taken on an electrothermal melting point apparatus. NMR spectra were recorded on a JEOL FX90Q instrument 
with tetramethylsilane as the internal reference, and mass spectra were recorded by the Mass Spectrometry Unit, Division of Entomology, CSIRO. Microanalyses were performed by the Australian Microanalytical Service, Melbourne.

2-Benzyl-(1) and 2-benzoylbenzoic acids (19) were obtained commercially. 2-(Naphthalene-1-yl)methyl-(2), 2-(naphthalene-2-yl)methyl-(3), 2-(1-naphthoyl)-(20) and 2-(2-naphthoyl)benzoic acids (21) were prepared for comparison according to a published method. ${ }^{5}$ The syntheses of 3-aryl-3,4-dihydro-1H-2-benzopyron1 -ones (13), (14), (15), (16), (17), and (18) and $o$-arylethenylbenzoic acids (22), (23), (24), (25), and (26) have been published recently. ${ }^{3,6)}$ The syntheses of chrysene1-carboxylic acid (30) and benz[c]phenanthrene-4carboxylic acid (31) will be published elsewhere. ${ }^{7)}$

$o$-Arylalkylbenzoic acids (4), (5), (7), (8), (9), (10) and (12) were prepared from the reaction of the triphenylphosphonium salt of ethyl 2-bromomethylbenzoate with an appropriate aromatic aldehyde derivative according to the following general method.

2-(2-Phenylethyl)benzoic acid (4). Ethyl 2-(2-phenylethenyl)benzoate was prepared from the triphenylphosphonium salt of ethyl 2-bromomethylbenzoate $(10.1 \mathrm{~g} ; 0.02 \mathrm{~mol})$ according to the literature, ${ }^{3)}$ and hydrogenated in ethanol $(100 \mathrm{ml})$ at $60 \mathrm{psi}$ in the presence of $5 \%$ palladium on charcoal $(0.5 \mathrm{~g})$ for $2 \mathrm{hr}$. The catalyst was filtered off and the filtrate concentrated to $20 \mathrm{ml}$. Potassium hydroxide $(2.0 \mathrm{~g})$ was added and the mixture refluxed for $2 \mathrm{hr}$. The solvent was evaporated to dryness. The residue was dissolved in water and neutralized with acetic acid. The product was extracted with ethyl acetate. After removing the solvent the residue was recrystallized from light petroleum $\left(80 \sim 100^{\circ} \mathrm{C}\right)$ to give 2-(2-phenylethyl)benzoic acid $(3.1 \mathrm{~g} ; 69 \%$ ), mp $133 \sim 134.5^{\circ} \mathrm{C}$ [lit. ${ }^{8)} \mathrm{mp} 131.5 \sim 132.5^{\circ} \mathrm{C}$ ]. The following compounds were obtained according to the above method:

2-[2-(thiophen-2-yl)ethyl]benzoic acid (5). mp 110 $111^{\circ} \mathrm{C}$. Anal. Found: C, 67.3; H, 5.1; S, 14.1. Calcd for $\mathrm{C}_{13} \mathrm{H}_{12} \mathrm{O}_{2} \mathrm{~S}: \mathrm{C}, 67.2 ; \mathrm{H}, 5.2 ; \mathrm{S}, 13.8 \%$. NMR $\delta$ $\left(\mathrm{CDCl}_{3}\right): 3.0 \sim 3.5(4 \mathrm{H}, \mathrm{m}), 6.75 \sim 8.19(7 \mathrm{H}, \mathrm{m}), 10.7$ (1H, bs). MS m/z: $232\left(\mathrm{M}^{+}, 9\right), 97$ (100).

2-[2-(naphthalene-1-yl)ethyl]benzoic acid (7). $\mathrm{mp}$ 153.5 $155^{\circ} \mathrm{C}$ (benzene). Anal. Found: C, 82.6; H, 5.9. Calcd for $\mathrm{C}_{19} \mathrm{H}_{18} \mathrm{O}_{2}: \mathrm{C}, 82.6 ; \mathrm{H}, 5.8 \%$. NMR $\delta\left(\mathrm{CDCl}_{3}\right)$ : $3.45(4 \mathrm{H}, \mathrm{s}), 7.2 \sim 8.3(11 \mathrm{H}, \mathrm{m})$. MS $m / z: 276\left(\mathrm{M}^{+}\right.$, 22), 142 (12), 141 (100), 115 (10).

2-[2-(naphthalene-2-yl)ethyl]benzoic acid (8). $\mathrm{mp}$ $154 \sim 155^{\circ} \mathrm{C}$ (ethanol). Anal. Found: C, 82.3; H, 6.0. NMR $\delta\left(\mathrm{CDCl}_{3}\right): 3.1(2 \mathrm{H}, \mathrm{m}), 3.45(2 \mathrm{H}, \mathrm{m}), 7.2 \sim 8.2$ (11H, m). MS m/z: $276\left(\mathrm{M}^{+}, 18\right), 142$ (12), 141 (100), $115(10)$. 2-[2-(indole-3-yl)ethyl]benzoic acid (9). $\mathrm{mp}$ 169 $170^{\circ} \mathrm{C}$ (ethanol). Anal. Found: C, 76.9; H, 5.8; N, 5.3. Calcd for $\mathrm{C}_{17} \mathrm{H}_{15} \mathrm{NO}_{2}: \mathrm{C}, 80.0 ; \mathrm{H}, 5.7 ; \mathrm{N}, 5.3 \%$ ). NMR $\delta\left(\mathrm{CDCl}_{3}\right): 2.95 \sim 3.54(4 \mathrm{H}, \mathrm{m}), 6.86 \sim 8.14(10 \mathrm{H}, \mathrm{m})$. MS $m / z: 265\left(\mathrm{M}^{+}, 10\right), 130(100)$.

2-(3-phenylpropyl)benzoic acid (10). mp 89 91 ${ }^{\circ} \mathrm{C}$. Anal. Found: C, 80.2; H, 6.8. Calcd for $\mathrm{C}_{16} \mathrm{H}_{10} \mathrm{O}_{2}: \mathrm{C}$, $80.0 ; \mathrm{H}, 6.7 \%$. NMR $\delta\left(\mathrm{CDCl}_{3}\right): 1.98(2 \mathrm{H}, \mathrm{m}), 2.73$ $(2 \mathrm{H}, \mathrm{t}), 3.09(2 \mathrm{H}, \mathrm{t}), 7.23(8 \mathrm{H}, \mathrm{m}), 8.02(1 \mathrm{H}, \mathrm{m}) . \mathrm{MS}$ $m / z: 240\left(\mathrm{M}^{+}, 100\right), 149$ (47), 136 (68), 131 (42), 108 (67), 91 (72).

2-(4-phenylbutyl)benzoic acid (12), from cinnamaldehyde. $\mathrm{mp} 68 \sim 69^{\circ} \mathrm{C}$. Anal. Found: C, 80.4; H, 6.9. Calcd for $\mathrm{C}_{17} \mathrm{H}_{18} \mathrm{O}_{2}: \mathrm{C}, 80.3 ; \mathrm{H}, 7.1 \%$. NMR $\delta\left(\mathrm{CDCl}_{3}\right)$ : $1.70(4 \mathrm{H}, \mathrm{m}), 2.65(2 \mathrm{H}, \mathrm{t}), 3.07(2 \mathrm{H}, \mathrm{t}), 7.2(8 \mathrm{H}, \mathrm{m})$, $8.03(1 \mathrm{H}, \mathrm{m}) . \mathrm{MS} m / z: 254\left(\mathrm{M}^{+}, 36\right), 145(23), 132(42)$, 117 (37), 91 (100).

2-(2,4-Dichlorophenoxymethyl)benzoic acid (6). Ethyl $o$-bromomethylbenzoate $(16.9 \mathrm{~g})$ was added to a solution of sodio 2,4-dichlorophenol prepared from sodium $(1.6 \mathrm{~g})$ and the phenol (11.5 g) in $n$-butanol. The mixture was heated on a steam bath for $2 \mathrm{hr}$. After cooling, the solution was diluted with water and extracted with ethyl acetate. The extract was washed with water and extracted with ethyl acetate. The extract was washed with water and dried $\left(\mathrm{Na}_{2} \mathrm{SO}_{4}\right)$. Evaporation of the solvent gave $19.6 \mathrm{~g}$ of an oil which on crystallization from ethanol gave ethyl 2-(2,4-dichlorophenoxymethyl) benzoate $(13.5 \mathrm{~g}), \mathrm{mp} 84 \sim 86^{\circ} \mathrm{C}$. Anal. Found: C, 58.6; $\mathrm{H}, 4.6 ; \mathrm{Cl}, 21.9$. Calcd for $\mathrm{C}_{10} \mathrm{H}_{14} \mathrm{Cl}_{2} \mathrm{O}_{3}: \mathrm{C}, 59.1$; $\mathrm{H}, 4.3 ; \mathrm{Cl}, 21.8 \%$. NMR $\delta\left(\mathrm{CDCl}_{3}\right): 1.39(3 \mathrm{H}, \mathrm{t}), 4.37$ ( $2 \mathrm{H}, \mathrm{g}), 5.54(2 \mathrm{H}, \mathrm{s}), 6.87 \sim 8.24(7 \mathrm{H}, \mathrm{m})$. MS $m / z: 326$ $\left(\mathrm{M}^{+}, 1.3\right), 324\left(\mathrm{M}^{+}, 2.0\right), 163(51), 135$ (100). The ester $(3.0 \mathrm{~g})$ was hydrolyzed in $10 \%$ potassium hydroxide in ethanol to give 2-(2,4-dichlorophenoxymethyl)benzoic acid (6) $(1.5 \mathrm{~g} ; 55 \%), \mathrm{mp} 170 \sim 172^{\circ} \mathrm{C}$ (ethanol). Anal. Found: $\mathrm{C}, 56.2 ; \mathrm{H}, 3.4 ; \mathrm{Cl}, 24.1$. Calcd for $\mathrm{C}_{14} \mathrm{H}_{10} \mathrm{Cl}_{2-}$ $\mathrm{O}_{3}: \mathrm{C}, 56.6 ; \mathrm{H}, 3.4 ; \mathrm{Cl}, 23.9 \%$. NMR $\delta\left(\mathrm{CDCl}_{3} /\left(\mathrm{CD}_{3}\right)_{2}-\right.$ $\mathrm{SO}): 5.56(2 \mathrm{H}, \mathrm{s}), 6.93 \sim 8.1(7 \mathrm{H}, \mathrm{m})$. MS $m / z: 298$ $\left(\mathrm{M}^{+}, 1.3\right), 296\left(\mathrm{M}^{+}, 2.1\right), 162(16), 135$ (100).

2-(2,4-Dichlorophenoxymethoxy)benzoic acid (11). Methyl salicylate $(4.45 \mathrm{~g})$, sodium $(0.67 \mathrm{~g})$ and 2,4dichlorophenoxymethyl chloride $(6.2 \mathrm{~g})$ were treated as above to give.

2-[2,4-Dichlorophenoxymethoxy]benzoic acid (11). $\mathrm{mp}$ 134 $136^{\circ} \mathrm{C}$. (ethanol). Anal. Found: C, 54.0; H, 3.1; $\mathrm{Cl}$, 22.5. Calcd for $\mathrm{C}_{14} \mathrm{H}_{10} \mathrm{Cl}_{2} \mathrm{O}_{4}: \mathrm{C}, 53.7 ; \mathrm{H}, 3.2 ; \mathrm{Cl}$, $22.7 \%$. NMR $\delta\left(\mathrm{CDCl}_{3} /\left(\mathrm{CD}_{3}\right)_{2} \mathrm{SO}\right): 5.83(2 \mathrm{H}, \mathrm{s}), 7.0 \sim$ 7.9 (7H, m). MS $m / z: 314\left(\mathrm{M}^{+},<1\right), 312\left(\mathrm{M}^{+},<1\right)$, 164 (53), 162 (85), 151 (85), 121 (100).

Gravitropic assay. A gravitropic assay was carried 
out on cress (Lepidium sativum) roots according to the method previously described. ${ }^{2 \alpha}$ ) Concentrations at which the plants exhibited normal root gravitropic response are noted $(0)$ in the table of results, while those at which no response to gravity was observed are noted $(t+)$. Where partial loss of gravitropism occurred, the results are noted $(+)$.

\section{RESULTS AND DISCUSSION}

Table I sets out the activities of various $o$ substituted benzoic acids and related derivatives in terms of their ability to completely or partially abolish the root gravitropic response in cress seedlings when applied at concentra-

Table I. Effects on Root Gravitropism of $o$-Substituted Benzoic Acids With a General Structure

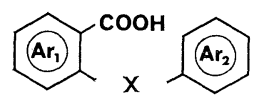

\begin{tabular}{|c|c|c|c|c|c|c|c|}
\hline & \multicolumn{3}{|c|}{ COMPOUNDS } & \multicolumn{4}{|c|}{$\begin{array}{c}\text { MOLAR } \\
\text { CONCENTRATIONS }\end{array}$} \\
\hline & $\mathrm{Ar}_{1}$ & $x$ & $\mathrm{Ar}_{2}$ & $10^{-5}$ & $10^{-6}$ & $10^{-7}$ & $10^{-8}$ \\
\hline 1 & & $\mathrm{CH}_{2}$ & & ++ & + & 0 & ० \\
\hline 2 & & $\mathrm{CH}_{2}$ & & ++ & + & 0 & 0 \\
\hline 3 & & $\mathrm{CH}_{2}$ & & ++ & + & 0 & 0 \\
\hline 4 & & $\mathrm{CH}_{2} \mathrm{CH}_{2}$ & & ++ & + & + & 0 \\
\hline 5 & & $\mathrm{CH}_{2} \mathrm{CH}_{2}$ & & ++ & + & 0 & 0 \\
\hline 6 & & $\mathrm{CH}_{2} \mathrm{O}$ & & ++ & 0 & 0 & 0 \\
\hline 7 & & $\mathrm{CH}_{2} \mathrm{CH}_{2}$ & & ++ & ++ & + & ० \\
\hline 8 & & $\mathrm{CH}_{2} \mathrm{CH}_{2}$ & & ++ & + & + & 0 \\
\hline 9 & & $\mathrm{CH}_{2} \mathrm{CH}_{2}$ & & ++ & $+t$ & + & 0 \\
\hline 10 & & $\left(\mathrm{CH}_{2}\right)_{3}$ & & ++ & + & O & $\circ$ \\
\hline 11 & & $\mathrm{OCH}_{2} \mathrm{O}$ & & $+t$ & + & 0 & 0 \\
\hline 12 & & $\left(\mathrm{CH}_{2}\right)_{4}$ & & $+t$ & + & 0 & ० \\
\hline 13 & & & & + & 0 & 0 & 0 \\
\hline 14 & & & & + & + & 0 & 0 \\
\hline 15 & & & & + & O & o & 0 \\
\hline 16 & & & & + & $t$ & 0 & 0 \\
\hline 17 & & & & ++ & + & + & 0 \\
\hline 18 & & & & ++ & + & + & 0 \\
\hline
\end{tabular}

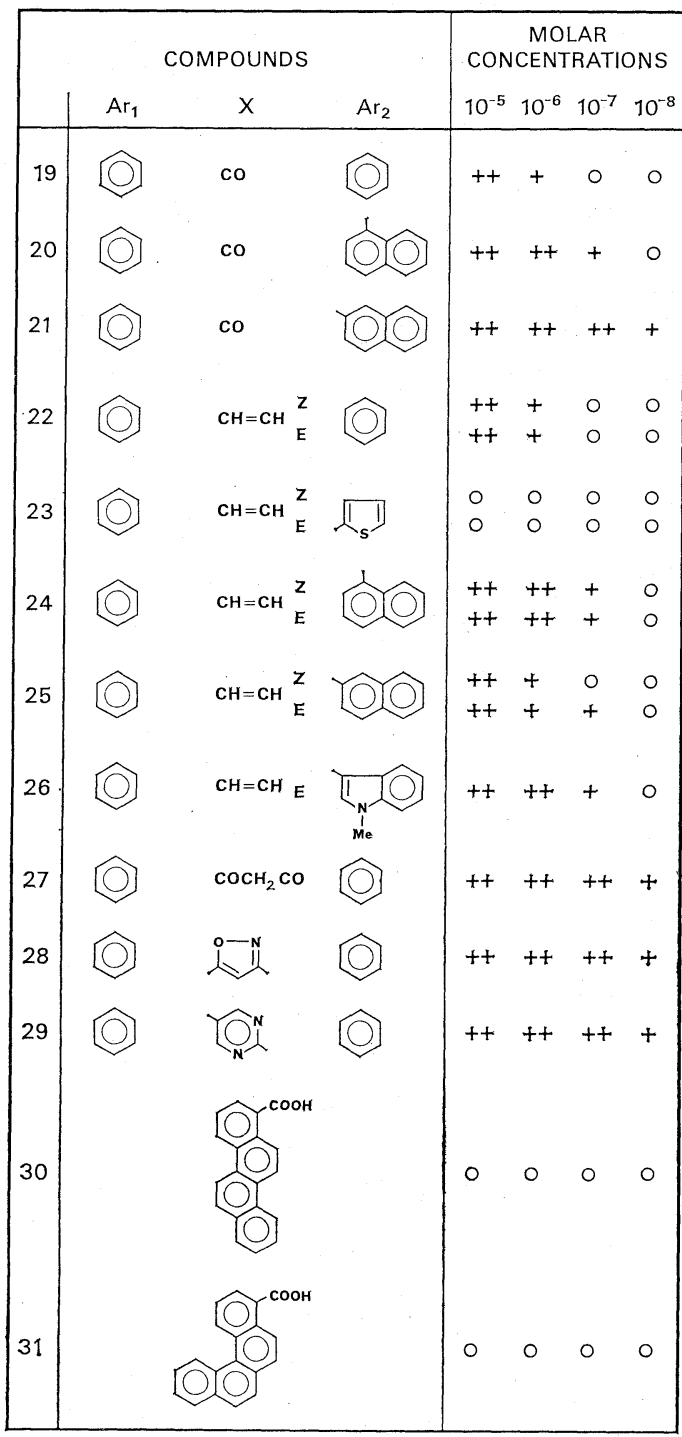


tions ranging from $10^{-5}$ to $10^{-8} \mathrm{M}$.

The majority of compounds studied possessed a benzoic acid moiety $\left(\mathrm{Ar}_{1}\right)$ or an analogous lactone, which was separated from a second aryl group $\left(\mathrm{Ar}_{2}\right)$ by a bridge of one to four atoms (X) involving either saturated bonds $(1 \sim 18)$ or partially unsaturated bonds (19 29). In other compounds studied, the benzoic acid moiety $\left(\mathrm{Ar}_{1}\right)$ was fused to the second aryl group $\left(\mathrm{Ar}_{2}\right)$ (30 and 31). The activities of compounds (27, 28 and 29) reported in the literature ${ }^{2 \mathrm{~d})}$ have been included in Table I for purposes of comparison. Compounds which were fully effective in abolishing the gravitropic response at $10^{-7} \mathrm{M}$ or less are regarded as extremely active, those fully effective at $10^{-6} \mathrm{M}$, as highly active and at $10^{-5} \mathrm{M}$, as moderately active.

Carboxylic acid derivatives containing one or two fully saturated bridging atoms between $\mathrm{Ar}_{1}$ and $\mathrm{Ar}_{2}$ (compounds 1 9, Table I) show a moderate to high anti-gravitropic activity and are broadly comparable in terms of activity to analogous compounds containing unsaturated bridging atoms (compounds 19 26, Table I). The corresponding lactone derivatives containing saturated bridging atoms (compounds 13 18, Table I) are of an order of magnitude less active than their carboxylic acid counterparts (compounds $22 \sim$ 26, Table I), probably reflecting their inability to be fully transformed into the free carboxylic acid under the conditions of the assay. ${ }^{2 \mathrm{~d} \text { ) }}$

In those moderately to highly active compounds in which the bridging atoms are fully saturated, the bridge itself is non-planar and hence cannot be co-planar with either of the aryl nuclei nor can the aryl nuclei be coplanar with each other. This is clearly in conflict with a conclusion based on a recent study that for root gravitropic activity the portion of the molecule attached to the arylcarboxylic acid must be planar or capable of being so. ${ }^{4}$ Rather it would appear that the stereochemical nature of the bridging atoms is not a critical requirement for activity and this implies that the bridging atoms may simply act as a link between the two aryl moieties allowing them to fit the receptor site.

Partially unsaturated bridging atoms would tend to be less flexible than saturated bridging atoms and hence the spatial criteria for matching the molecule to the receptor site are likely to be more critical. This is reflected in the contrast between the nearly constant activities of compounds with saturated bridging systems containing one to four atoms (compounds $1,4,10,12)$ and the variable activities of unsaturated bridged compounds. In the latter group, those containing three or four bridging atoms $(27,28,29)$ are an order of magnitude more active than those with one or two bridging atoms.

At first sight, compound (21) appears to be unusually active for a molecule with one unsaturated bridging atom, but this high level of activity can be accounted for if (21) is regarded as containing a three atom bridging system between two phenyl rings. A similar argument can explain the significantly lower activity of the isomeric compound (20) since, in this case, only a two atom bridging system between the two phenyl rings is possible.

One could predict that under conditions of optimum overlap between the molecule and the receptor site, molecules with less flexible unsaturated bridging systems are likely to interact more strongly and hence be more active than those with more flexible saturated bridging systems because there are fewer alternative conformations available for them to adopt. This could account for the significantly greater activity of compounds with unsaturated bridging systems containing 3 or 4 atoms as compared with compounds with saturated bridging systems of 1 to 4 atoms.

The fused ring carboxylic acid derivatives (30 and 31), in which the bridging system of atoms can be regarded as rigid and the whole molecule as planar, were inactive at the highest concentration tested. This suggests that coplanarity of the aryl moieties is unfavourable for anti-gravitropic activity, which is in agreement with an earlier suggestion based on the very weak activity of a fluorene carboxylic acid derivative. ${ }^{9)}$ 
The comparable activity of cis and trans ethylene bridged compounds ${ }^{31}$ has been attributed to the ability of both isomers to adopt an out of plane configuration which would allow the aryl moieties to interact with the receptor site. The cis and trans thienyl ethylene bridged compounds (23) were unusual in being significantly less active than either the phenyl ethylene bridged analogue (22) or the corresponding thienyl ethane bridged derivative (5). This may be due to a $\pi$-bonded interaction of the electron-rich thienyl group with the phenyl ring stabilizing the ethylene bridged compound in a planar and hence inactive configuration. However, the high activity of the $\mathrm{N}$ methylindole ethylene bridged compound (26), in which a similar $\pi$-electron delocalization could occur, suggests that the forces favouring planarity can be counterbalanced by interaction forces between the molecule and the receptor site. Thus, ethylene bridged molecules containing large, strongly interacting heteroaryl groups, e.g., $N$-methylindolyl, could adopt a non-planar, active configuration whilst those containing small, weakly interacting heteroaryl groups, e.g., thienyl, could assume a planar, inactive configuration.
Acknowledgments. The author wishes to thank Dr. J. N. Phillips and Dr. J. L. Huppatz for their helpful discussion and Miss S. T. Hyde for skilled technical assistance.

\section{REFERENCES}

1) B. T. Brown, O. Johansen and W. H. F. Sasse, Experientia, 28, 1290 (1972).

2) (a) B. T. Brown, O. Johansen, G. F. Katekar and W. H. F. Sasse, Pestic. Sci., 4, 473 (1973); (b) A. E. Geissler, J. L. Huppatz and G. F. Katekar, Pesti. Sci., 6, 441 (1975); (c) G. F. Katekar, Phytochemistry, 15, 1421 (1976); (d) R. L. N. Harris, J. L. Huppatz and T. Teitei, Pestic. Sci., 11, 439 (1980).

3) T. Teitei, Agric. Biol. Chem., 45, 1669 (1981).

4) G. F. Katekar and A. E. Geissler, Phytochemistry, 20, 2465 (1981).

5) E. de B. Barnett and N. R. Campbell, J. Chem. Soc., 1031 (1935).

6) T. Teitei, Aust. J. Chem., 35, 1231 (1982).

7) A. J. Jones and T. Teitei, Aust. J. Chem., in preparation.

8) J. W. Wilson, III, C. L. Zukle, E. L. Anderson, J. J. Stehle and G. E. Ullyot, J. Org. Chem., 16, 792 (1951).

9) G. F. Katekar and A. E. Geissler, Plant Physiol., 66, 1190 (1980). 